\title{
Overcoming the Odds: Strategies Used By Women Entrepreneurs in Milk Microenterprises in Kenya
}

\author{
Dolphine A. Odero-Wanga*, Milcah W. Mulu-Mutuku and Adijah Ali-Olubandwa \\ Department Applied Community Development Studies, Egerton University, Egerton, Kenya
}

\begin{abstract}
Kenyan women are increasingly participating in the microenterprise sector to earn a living for themselves and their families. However, they are constantly faced with numerous challenges that force them to rely on a number of strategies to counteract the unfavorable business environment they find themselves in. This paper examines the strategies used by women in milk microenterprises to ensure the survival of their enterprises in Kenya. The study was carried out in Nairobi, Kiambu and Nakuru districts. 108 women entrepreneurs participated in the study. Interviews and observations were used to collect data among women who were selected using stratified, simple random, purposive and snowball sampling methods. Strategies used by women to sustain their enterprises included accessing credit facilities from relatives and friends; using low level technologies; operating their businesses illegally to avoid heavy licensing costs; and managing their enterprises close to home. While these strategies allowed the women to operate their enterprises at a certain level, they are unlikely to encourage the growth and sustainability of women owned microenterprises. This call for policy interventions that can create favorable environment that promote women's entrepreneurship and facilitate their effective participation in the microenterprises within the dairy industry in Kenya.
\end{abstract}

Keywords: Women, entrepreneurs, microenterprises, strategies, milk, Kenya

\section{Introduction}

In Kenya, as in most parts of the world, the majority of poor people are women. The feminization of poverty has been accentuated by large inequalities and women suffer disproportionately as cultural and traditional practices restrain equal access to resources, decision on allocation and use of those resources (Shaohua \& Ravallion, 2008; World Bank, FAO, IFAD,2009). The changing nature of households particularly the emergence of female headed households coupled with triple burden of work as women cope with house work, childcare and economic production also make them more vulnerable to impoverishment as they have less time to earn money outside home (Momsen, 2004).

In recent years, participating in the microenterprise sector has been recognized as an effective way of alleviating women's poverty by promoting their selfemployment. Microenterprises; with low capital investment, use of basic technology, reliance on family labour and proximity to home sites; have the potential for creating employment avenues for a population with low and moderate skills of which women form the majority (UNCTAD, 2000; Mohanti, 2004). In this paper we perceive microenterprise as an enterprise that is operated under single ownership; employs less than

\footnotetext{
${ }^{*}$ Corresponding author
}

10 people and managed with very little capital investment and high manual labour (OyelaranOyeyinka, 2000; Bosire \& Etyang, 2004).

With the implementation of economic reform policies, Kenyan women have tended to enter the microenterprise sector in an effort to combat declining real wages and diminishing opportunities for wage employment among themselves and their male counterparts. Among various income generating activities, the dairy sector, in particular, provides many opportunities for women to operate microenterprises because of the growing demand for milk and milk products in the country. As these women participate in the dairy microenterprise sector, they experience challenges such as limited access to productive resources, particularly capital and technology; lack of market information; and lack of credit (Jagero \& Kushoka, 2011; Odero-Wanga et al., 2009, 2010). Although men in the dairy microenterprise sector are faced with similar challenges, women in the sector are particularly vulnerable due to unequal access to productive resources, limited mobility and unavailability of time stemming from domestic responsibilities (World Bank, FAO, IFAD, 2009: Momsen, 2004). These factors restrict women's capacity to participate effectively in business activities such as attending training and searching out new markets and possible suppliers. Despite the discouraging business http://www.worldscholars.org 
environment in which these women find themselves, they are actively devising ways and means to ensure survival of their enterprises. In this paper we examine strategies used by women in the milk microenterprises to overcome some of the challenges in their efforts to empower themselves and to provide for their families.

\section{The Study Area}

The study was carried out in three districts in Kenya: Nairobi, Kiambu and Nakuru (Figure 1). Nairobi is the capital and largest city of Kenya. It is located at the southern end of Kenya's central highlands and lies at an altitude of between $1600 \mathrm{~m}$ and $1800 \mathrm{~m}$ above sea level. It is adjacent to the eastern edge of the Rift Valley. Nairobi is the most populous city in East Africa with a current estimated population of 3 million. The main economic activities in the district include industrial production of various goods, trading, tourism, professional business services and commercial enterprises. The livelihood of most inhabitants of Nairobi comes from the informal economic activities since formal wage employment has been decreasing as the public sector continues to retrench its employees due to restructuring programs introduced in $1990 \mathrm{~s}$ (Government of Kenya (GOK), 2002). Because of its large urban population, Nairobi provides the largest market for milk and dairy products although it has near zero production of its own. Kiambu District is adjacent to the northern border of Nairobi and has a population of 914,000. The district lies at an altitude of between $1200 \mathrm{~m}$ and $2250 \mathrm{~m}$ above sea level and is characterized by hills, plateaus and high level plains (Central Bureau of Statistics (CBS), 2001). Kiambu is predominantly rural and has a total area of 1,324 $\mathrm{Km} 2,90 \%$ of which is arable land (Onduru et al., 2006). The major economic activity in the district is agriculture with the main activities being dairy production, poultry keeping, crop production and pig farming. Kiambu District has a long history of small holder dairy production with farmers allocating about $41 \%$ of family land to dairy farming (Staal et al., 1998). Most of the milk produced in Kiambu is sold in Nairobi.

Nakuru District is located in the north west of Nairobi. It is situated at an altitude of $1859 \mathrm{~m}$ above sea level and it is within the Great Rift Valley whose formation gave rise to a unique natural structure. The district is the home of Lake Nakuru known for its large number of flamingoes that can be seen foraging in the shallow lake. The major economic activities include agriculture, manufacturing, tourism and commerce. The district is known for its vast agricultural potential with numerous small farms and vast agricultural enterprises. Dairy farming is a key economic activity and provides the inputs for various milk processing plants as well as milk enterprises in the district.

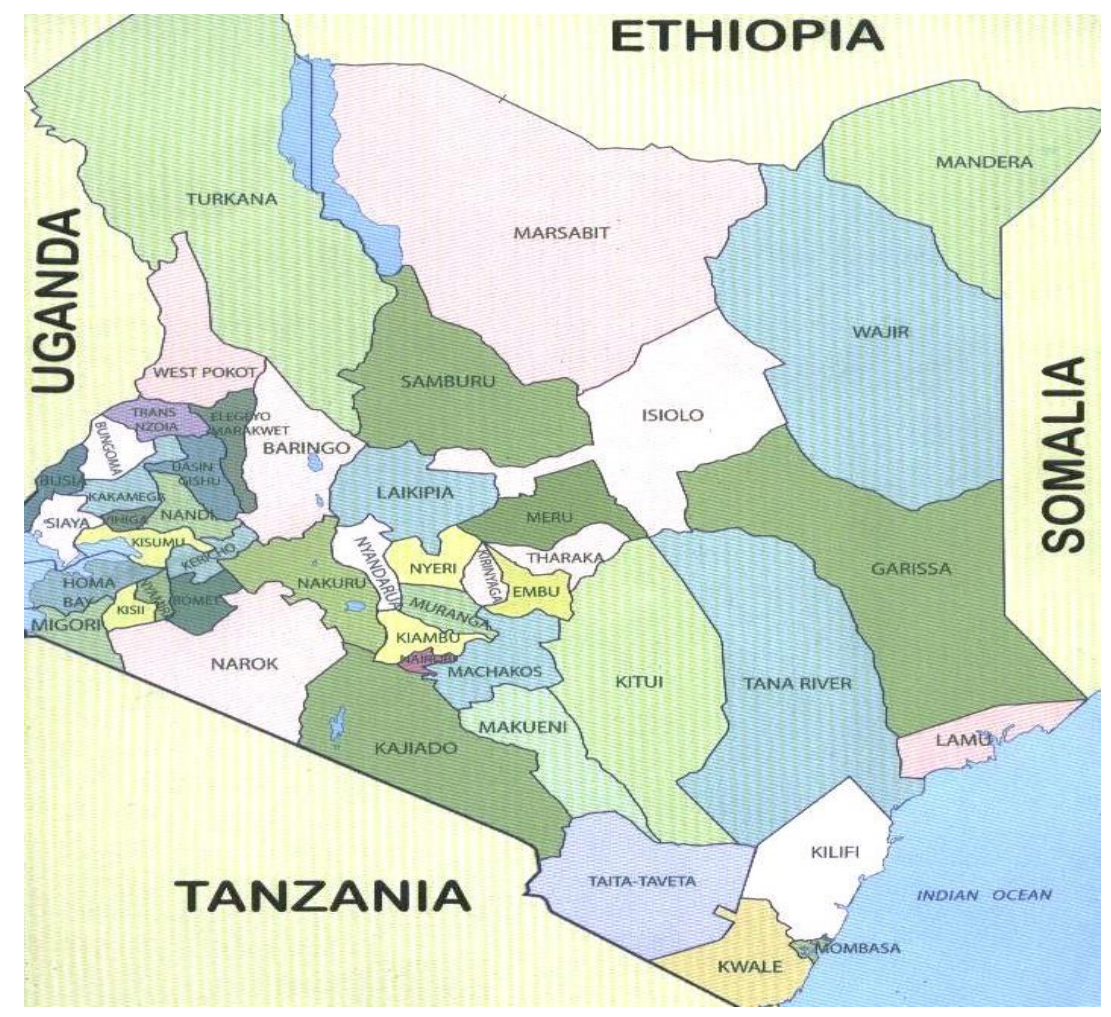

Figure 1. Map of Kenya. 


\section{Methodology}

\section{Study population and sample selection}

The participants in the study were drawn from a population of women entrepreneurs engaged in microenterprises within the dairy industry in Nairobi, Kiambu and Nakuru districts of Kenya. The sample consisted of 108 women. The sampling frame was compiled using information obtained from The Kenya Dairy Board (a body responsible for regulating milk businesses in the country) and a sample selected using stratified and simple random sampling as well as purposive and snowball sampling methods. Purposive and snowball sampling were used because during participants' identification, it was discovered that several of the registered enterprises had closed down and others had been started, a majority of which had not registered with the Kenya Dairy Board. In order to cover a good representation of the dairy microenterprise owned by women, participants were drawn from various parts of the three districts.

\section{Data collection and analysis procedures}

Interviews and observations were used to collect data. The interview schedule contained both open and closed ended questions which focused on technology available and used by women in their enterprises, types of credit sources available and accessible to these women, challenges experienced by the women in managing their enterprises and the strategies used to address these challenges. The interviews took place at the site of the enterprises so that they could be enriched by direct observations on the situation of the enterprises in their natural setting. Specifically, the observations focused on condition of business premises, equipment used and interpersonal relations between the entrepreneurs and their customers. The collected data were analyzed using frequencies and percentages.

\section{Findings and Discussions}

\section{Profile of the participants}

The study participants differed from one another in several ways. They were of diverse levels of education with majority (75\%) having secondary and post secondary education. Table 1 indicates the education levels of the respondents.

Table 1. Respondents' level of education

\begin{tabular}{lc}
\hline Respondent's education level & Percent (\%) \\
\hline No formal education & 2.4 \\
Primary education & 22.6 \\
Secondary education & 47.6 \\
Post Secondary education & 27.4 \\
\hline
\end{tabular}

Although majority of the respondents had secondary level education, this level of education does not guarantee any employment other than in the informal sector in Kenya. The generally high levels of education among the women, however, implies that given the right support, these entrepreneurs have the potential to access and use information necessary for the development and sustainability of their enterprises.

Many factors motivated the women to start dairy microenterprises with majority $(62.3 \%)$ starting the business to earn a living for themselves and their families. $27.2 \%$ went into the business because of the readily available market for milk and milk products while $13.2 \%$ started the business to create a market for raw milk, either from their own farm or for other farmers. Another $8.8 \%$ went into the business because they had been trained in dairy production and therefore opted to utilize their knowledge and skills. Majority of the entrepreneurs had managed their enterprises for a period of three years and less as indicated in Table 2.

Table 2. Age of emprises

\begin{tabular}{lc}
\hline Age of enterprise & Percent $(\%)$ \\
\hline Less than one year & 28.6 \\
1-3 years & 44.6 \\
4-7 years & 15.2 \\
Over 7 years & 11.6 \\
\hline
\end{tabular}

The above results create concern over the sustainability of enterprises owned by women in the dairy microenterprise sector in Kenya.

Concerning the sources of milk supply, majority of the entrepreneurs got their milk supplies from individual farmers who transported the milk to the enterprises on a daily basis. Other sources were own farm, milk cooperative societies, larger dairies and milk peddlers. Table 3 presents the various suppliers of milk to women's enterprises.

Table 3. Suppliers of milk

\begin{tabular}{lr}
\hline Milk supplier (\%) & Percent \\
\hline Individual farmers & 60.0 \\
Own farm & 20.9 \\
Milk cooperative societies & 18.3 \\
Milk peddlers & 12.2 \\
Large dairies & 7.8 \\
\hline
\end{tabular}

The dairy sector in Kenya is mainly dominated by small holder farmers who often prefer to sell their milk to the microenterprises as they get paid promptly. Hence, for the most part, the entrepreneurs did not have problems with the milk supply except during dry season when the farmers had generally low levels of milk production. While majority of the entrepreneurs used one supplier, $17.4 \%$ used more 
than one source of milk supply. This sometimes created problems for the women as various suppliers did not have the same milk quality. Some suppliers adulterated their milk with water and unacceptable chemicals to increase milk volume and prolong milk life respectively affecting the quality of milk sold to the customers by the entrepreneurs.

\section{Credit facilities}

Credit facilities form an integral part of microenterprise development. It is essential in starting, expanding or improving the productivity of an enterprise. As entrepreneurs, however, it is widely acknowledged that women in Kenya as in most African countries have limited access to credit (Katepa-Kalala,1999; Odero-Wanga et al., 2010). This has mainly been due to the fact that these women lack acceptable collateral required as security by formal financial institutions (Akingunola \& Onayemi, 2010). Although microfinance institutions have been set up to deal with the weakness of formal banks, these too have conditions that are not friendly to women.

Like their counterparts, majority of women (76\%) in this study did not acquire credit from formal financial institutions. The most used sources of financial assistance $(81 \%)$ were friends and relatives, self-help groups and money lenders. Explaining their preference for seeking financial assistance from informal institutions, the women stated that while financial services provided by formal institutions asked for collateral and other tough lending conditions, the informal sources had no strict condition. For example, financial assistance from friends and relatives were often refunded without interests and payment schedules were very flexible.

Although the informal sector provided flexible avenues for these women to access credit, most of the financial assistance from these sources was not sufficient for effective management of their enterprises. Financial assistance from friends and relatives were unreliable and in small amounts. Some credit sources such as money lenders demanded high repayments prohibiting the women from owning money they generated. This negatively affected the quality of products and the income derived from their enterprises. Further, the limited access to credit also prevented these women from taking advantage of profitable opportunities as they became available. This state of affairs has major implications on sustainability of women owned enterprises due to strained financial resources that can be received from the informal quarters. This ends up affecting the overall welfare of the family as it has been shown that women spend more of their income on their households (Katepa-Kalala, 1999; Kimani \&Kombo, 2010).

\section{Technology}

Technology plays a central role in the development process of an enterprise. It is a major supply factor and a key determinant in improving female owned enterprises leading to increased production, new or changed products or products of higher quality and income. Various types of technical information in dairy industry were found to be available to women entrepreneurs in this study. Information concerning types and sources of equipment, their modes of operation and maintenance was available. The other available information covered measuring equipment, testing equipment, boiling and cooling equipment, and equipment for converting raw milk into various dairy products, packaging and sealing techniques.

Concerning processing techniques of various dairy products, various types of information were available. These included techniques on cooling and pasteurization of fresh milk and production of concentrated milk products. Available also was information on the production of fermented milk products such as yoghurt using simple techniques that require use of household equipment as well as high level technologies requiring use of complicated equipment such as incubators. Similarly information on the processing of fat base milk products such as ice-cream, butter, cheese and ghee was also available. The main source of technical information for these women was friends and relatives (60\%) with $17 \%$ sourcing information from previous employment, $16 \%$ from short courses and 9\% from training in college.

In spite of the availability of technological information, majority of the women in the study area were not able to use new technologies due to lack of access to credit and training (Odero-wanga et al., 2010). Thus majority resorted to using low level technology that were generally very simple, manually operated and energy consuming. Examples of such technologies included the use of body senses such as smell, sight and taste to test for quality of raw milk. Match sticks were also use to determine if milk had been adulterated by adding water to increase volume. Specifically, this technology involved dipping a lighted match stick in the milk. The match stick going off was an indication that raw milk had abnormally high levels of water.

Another simple technology used by the women was with regard to preservation of milk. Since milk is a perishable commodity, cooling was used as a method of preservation. Most entrepreneurs (65\%) used household refrigerators as their cooling equipment. Others (10\%) simply put milk in a basin of cold water. This, however, did not preserve milk for a long period. Others (70\%) boiled milk using paraffin or charcoal kitchen stoves to preserve the 
milk. Packaging and sealing of milk was also done using simple technology. Majority of the entrepreneurs interviewed (78\%) did not package their products but used customers' packaging materials such as plastic containers. Often customers did not mind carrying their own packaging materials when they went to purchase milk from these entrepreneurs. Those who packaged their products used simple unlabelled transparent polythene bags which were sealed by use of candles.

While these technologies allowed the women to operate their enterprises at a certain level, they are unlikely to improve the production capacities of women owned enterprises due to lack of product differentiation facilitated by technology use. Furthermore, use of such technologies increase women's workload demanding more time that they do not have. These women, therefore, need to be provided with training and support particularly with regard to access to credit if they are to use improved technology which will eliminate some of the fatigue and drudgery caused by low level technology they are currently using. Lack of this is likely to contribute to making women in milk microenterprises in Kenya redundant further pushing them into destitution (Singh, 2005).

\section{Regulatory requirements}

Although majority of microenterprises in Kenya are in the informal sector of the economy, there are regulatory requirements that need to be met in order for them to legally operate. For example, to operate a dairy enterprise one is required to register with the Kenya Dairy Board. In addition one is expected to have an operating license as well as a public health certificate permitting one to handle food products from the local authorities. These requirements come with a cost that often present serious challenge to women owned microenterprises. Further, the procedures to be followed to obtain the necessary documents are long and confusing (Mwobobia, 2012). As a result women resort to operating their enterprises illegally. Majority of the women (90\%) in this study had not obtained operating licenses for their enterprises exposing them to constant harassment from local authorities.

Operating a way from central business districts (CBDs), where local authorities concentrated most of their efforts, was one strategy these women used to avoid harassment. The other strategy used by the women was closing down their enterprises during inspection times by law enforcement officers. This closure sometimes went for days or even weeks implying lose of income for these enterprises. This problem was further compounded by the fact that regulatory requirements did not only affect the women entrepreneurs but their suppliers as well. In most cases the suppliers did not have the necessary requirements for transporting milk or had failed to pay certain fee. This often resulted into their milk being impounded by authorities leaving women entrepreneurs with no milk supply.

Operating in such an environment diminishes women's capacity to effectively manage their enterprises and as such they are unlikely to get any meaningful income to provide for themselves and their families let alone expand their enterprises. If microenterprises are to contribute significantly to improvement of women's livelihoods, efforts must be made to simplify and reduce transaction costs of business registration and licensing. Such a move will not only facilitate full participation of women in this sector but also enable them to benefit from any training or advisory services which they often miss out on as a result of not operating legally.

\section{Women's triple roles}

As women in Kenya start participating in the microenterprise sector to earn a living, they continue to carry a burden of domestic responsibilities. The gender division of labor within the household implies that these women continue to assume primary responsibility of domestic work, care of dependants and economic production (Momsen, 2004; Blin, 2006). Because of these responsibilities women in this study often ran into conflict with regard to time, energy and resources. This forced them to devise means to ensure survival of their enterprises which had far reaching implications on their output and productivity.

One strategy used by all the women in the study to address this challenge was to manage their enterprises close to or within their homes. This allowed them to balance their productive and reproductive roles. However, many women were forced to open their enterprises as late as 9am in the morning and close during lunch time and early evening to take care of domestic responsibilities. This had implications on the time spent in the business with these women spending less time in their enterprises compared to their male counterparts who opened their enterprises as early as 6am and closed down as late as $8 \mathrm{pm}$. Furthermore, the best times for selling milk in the study areas were early morning hours and in the evenings as most customers used milk to prepare breakfast and evening tea. Thus majority of the women entrepreneurs lost out in the sale of their milk products during these critical hours. For women managing their enterprises from within the homes, carrying out multiple tasks at the same time was another strategy used. It was common to observe these women carrying out domestic responsibilities such as washing clothes, utensils, 
cleaning the house or taking care of a baby at the same time bargaining with a customer on the prices of the products. The customers also seemed to understand the plight of these women and would patiently interact with them as they performed domestic chores. For example, there were many instances where a customer would come to the shop and find no attendant. However, instead of leaving, they would knock to alert the entrepreneur of their presence and wait patiently for her to appear.

The strategies used by women in this study enabled them to "juggle" their limited time between income generating activities and unpaid domestic work. However, these strategies gave women no slack time to invest in activities such as attending training and looking for markets that are likely to increase income from their enterprises. For example, the heavy workload prevented these women from operating their businesses in the CBDs where markets are more lucrative. As a result they concentrated on local markets where customers' purchasing power were lower, sometimes forcing them to use strategies such as reducing the prices of their commodities even though this meant loss of profit. The heavy workload also prevented the women from participating in social networks that goes beyond their places of residence thus limiting their opportunities to access market information, financial and non financial support. These findings illustrate the need for policy approaches that focus on women's productive and reproductive roles if women are to effectively participate in economic production.

\section{Conclusions}

The microenterprise sector in the dairy industry in Kenya continues to be a major income earner, and an important strategy for women to contribute to family income. As women participate in this sector, they experience numerous challenges that move them to devise strategies to ensure survival of their enterprises. However, for the most part, the strategies used have major implications on the growth and sustainability of their enterprises. In this study, strategies used by women entrepreneurs to deal with the challenges of credit access, technological input, non supportive regulatory frameworks and women's triple roles had serious consequences on the productive capacity of their enterprises in terms of quality of products and income derived from these enterprises.

The implication is that such strategies are unlikely to facilitate the growth of women owned microenterprises in the dairy sector and as such, the enterprises are unlikely to move from the informal to the formal economy. If women in the dairy microenterprises in Kenya have to be assisted to manage sustainable enterprises that are to grow and contribute significantly to their livelihoods, policy interventions need to be put in place to increase the success rates of women owned enterprises. Specifically, policy intervention is needed to make technological input more accessible and affordable. Since most women get their financial assistance from the informal sector, there is need for policies that will streamline the delivery of credit from this sector. In addition, policies aimed at strengthening business extension services would play a key role in providing necessary information to women entrepreneurs. These policies should, however, be gender responsive as gender blind policies have contributed to heavy workload for women, low technical knowhow and poor access to credit. Equally important is the avoidance of top down approaches that deny women's participation in decision making process that affects them and their enterprises.

Providing an enabling environment for the sustainability and growth of women owned microenterprises is an important step if Kenya is to achieve an appreciable success towards attaining the first millennium development goal of halving poverty and hunger by 2015; and to achieve a $10 \%$ annual economic growth as well as moving the country to the middle income bracket as envisioned in Kenya's vision 2030. In addition, increasing women's income through participation in sustainable microenterprises can result into improvement of their roles in their households as well as increasing their confidence as a result of economic success of their business.

\section{References}

Akingunola, R., \& Onayemi, S. (2010). The role of informal finance in the development of women micro-business in Nigeria: A case study of Ogun and Oyo states. International Journal of Academic Research, 5(2), 331-338.

Blin, M. (2006). Export-oriented policies, women's work burden and human development in Mauritius. Retrieved from http://www.soas.ac.uk/economicsworkingpapers.

Bosire, J., \& Etyang, M. (2004). The effects of experiential factors on business skills cognition: The case of micro-scale entrepreneurs in Kenya. Egerton Journal, 5(2), 172-186.

Central Bureau of Statistics (CBS). (2001). The 1999 population and housing census vol 1. Ministry of Finance and Planning. Republic of Kenya.

Government of Kenya (GOK). (2002). Economic survey. Government Printers, Nairobi. Jagero, N., \& Kushoka, I. (2011). Challenges facing women microenterprise in Dar es Salaam, Tanzania. International Journal of Human Resource Studies, 1(2), 1-9.

Katepa-Kalala, P. (1999). Assessment report on: women and poverty, and the economic empowerment of women. Paper presented at the Economic Commission for Africa Sixth African Regional Conference on women. Addis Ababa, Ethiopia.

Kimani, E.N., \& Kombo, D.K. (2010). Gender and poverty reduction: A Kenyan context. Educational research and Reviews, 5(1), 24-30.

Mohanti, O. (2004). Women in management of micro-enterprises: Problems and prospects. Journal of Social Sciences, $8(3), 245-251$. 
Momsen, J. (2004). Gender and development. London: Routledge.

Odero-Wanga, D., Ali-Olubandwa, A., \& Mulu-Mutuku, M. (2010). Women in milk Microenterprises in Kenya: Challenges and opportunities. International Journal of Sustainable Development, 3(11), 42-49.

Odero-Wanga, D., Mulu-Mutuku, M., \& Ali-Olubandwa, A. (2009). Value added milk products: Constarints to women in milk enterprises in Kenya. Journal of Development and Agricultural Economics, 1(7), 144-149.

Onduru, D.D., De Jager A., Wouters, B., Muchera, F.N., Gachimbi, L., \& Gachini, G.N. (2006). Improving soil fertility and farm productivity under intensive crop-dairy smallholdings: Experiences from farmer field schools in the highlands of Kiambu Distict, Central Kenya. Middle-East Journal of Scientific Research, 1(1), 31-49.

Oyelaran-Oyeyinka, B. (2000). The technology and institutions for private small and medium firms: The engineering industry in
Nigeria. ATPS working paper No. 15. Nairobi: African Technology Policy Studies.

Shaohua, C., \& Ravallion, M. (2008). The developing world is poorer than we thought; but no less successful in the fight against poverty". Washington DC: World Bank.

Singh, M. (Ed.) (2005). Meeting basic learning needs in the informal sector. New York, NY: Springer.

Staal, S., Chege, L., Kinyanjui, M., Kimani, A., Lukuyu, B., Njumbi, O.M., ... \& Wambugu, M. (1998). Characteristics of dairy systems supplying the Nairobi milk market: A pilot survey of Kiambu District for the identification of target groups of producers. Nairobi: Kenya.

UNCTAD. (2000). Women entrepreneurs in Africa: Experiences from selected countries. Geneva: United Nations.

World Bank, FAO, IFAD (2009). Gender and agriculture source book. Washington DC: World Bank. 